\title{
Náboženská víra a vztah k historii - analýza existence vzájemného propojení
}

\author{
Religious Faith and Relationship to History \\ - Analysis of Interconnection
}

Acta Fakulty filozofické Západočeské univerzity v Plzni

2019, Vol. 11 (1), 1-18 DOI: https://doi.org/10.24132/actaff.2019.11.1.1 http://ff.zcu.cz/research/edicni-cinnost/acta/ ISSN 2336-6346

\author{
Veronika Hásová, ${ }^{*}$ Jan Váně
}

Západočeská univerzita v Plzni

\author{
Jiři Vinopal \\ Univerzita Karlova \\ Dušan Lužný \\ Univerzita Palackého v Olomouci
}

\begin{abstract}
The purpose of this text is to attempt to test the connection between people's religiosity and their relationship to history, and also to provide some new knowledge about this relationship in the Czech Republic. According to theories, it is assumed that religion and history are somehow connected. This is why we are trying to obtain knowledge about the relationship between people's religiosity and their historical consciousness. This knowledge should shed light on the role of religious memory. We assume that the process of how religious attitudes are justified by historical stories helps to form a relationship between people's religiosity and their attitude towards history. We use data from the research entitled Sociologický výzkum historického vědomí 2010 (Sociological Research of Historical Consciousness). Linear regression and analysis of tables show that the examined relation is not as clear as we expected. Individuals with a different level of religious memory also have different attitudes towards historical consciousness. Practicing believers more often lean towards the category of historical consciousness called "positive affirmation" in contrast with non-believers, who have a tendency towards noetic instrumentalism and positive affirmation instead of historical nihilism as we expected. Furthermore, it was not proven that there is a causal relationship between believers and the scores from tests of historical knowledge. This relationship is mediated by cultural capital (education) and socio-economic status.
\end{abstract}

\section{Keywords}

religious memory, historical consciousness, Czech Republic, quantitative research, believers

\footnotetext{
* Corresponding Author: Veronika Hásová, Katedra sociologie, Fakulta filozofická Západočeské univerzity v Plzni, Sedláčkova 15, 30614 Plzeň, a Katedra sociologie, Filozofická fakulta Univerzity Karlovy, nám. Jana Palacha 2, 11638 Praha. E-mail: hasova@kss.zcu.cz.
} 


\section{Úvod}

Záměrem studie je ověřit předpoklad o možném propojení historického vědomí, vztahu k historii s náboženskou vírou. Jinak řečeno, ptáme se, zda v určité míře můžeme na základě výzkumu historického vědomí obyvatel v České republice určit, jak/zda náboženská víra diferencuje jedincův př́stup k historii. Svou pozornost proto obracíme tímto naznačeným směrem z několika důvodů.

Jak náboženská víra, tak historické vědomí jsou indikátory odkazující k určitému druhu paměti. Pamět v našem kontextu chápeme jako prostředek udržující určité vzorce chování, jednání a myšlení napřrič generacemi. V tomto ohledu je pro nás deklarovaná víra indikací určité náboženské paměti daných jedinců. A to z toho důvodu, nebot i když výzkumy ukazují, že mezigenerační přenos víry slábne (Laudátová, Vido 2010; Paleček, Vido 2014; Paleček 2015; Váně, Hásová 2017), jsou pro nás úspěšné přenosy víry (deklarované religiozity) spojitou součástí náboženské paměti. Nemusí jít o identické přenesení vzorců náboženského jednání a myšlení z generace na generaci. Naopak počítáme s tím, že dochází k selekcím a inovacím v náboženské paměti, respektive, že může docházet k proměnám obsahu náboženské víry. Náboženskou pamět pro potřeby textu chápeme jako míru úspěšnosti přenosu vzorců chování, jednání a myšlení spojených s náboženskou vírou (dále srov. Lužný, Váně 2017). To znamená, že jedinci s odlišně deklarovanou religiozitou mají různou úroveň náboženské paměti. Obdobně vztah k historii a historickému vědomí odkazuje na pamět historickou, kterou definujeme jakožto sdílené porozumění historickým událostem a vlastním postojem jedinců ke znalosti dějin a dějinám jako takovým.

V době, která je pak charakteristická tlakem na modernizaci a vzrůstající individualismus je pamět rovněž něčím, co je ohroženo, ale zároveň klíčovým zdrojem identity. Pro náš záměr si pak v souvislosti s náboženskou pamětí vybíráme pamět historickou, protože jednak na úrovni teorie (viz níže) předpokládáme, že role náboženství ve společnosti a vztah jedince k historii spolu souvisí, a jednak proto, že historickou pamět chápeme jako legitimizační prostředek víry. Jinak řečeno, vycházíme z předpokladu, že náboženští jedinci jsou mnohem častěji konfrontováni s ospravedlněním svého postoje a toto ospravedlnění dle nás probíhá právě odkazem k historii, tj. specifickým historickým událostem s legitimizačním potenciálem. Tento předpoklad ověřujeme na základě námi prováděných analýz, které mají osvětlit, zda opravdu víra diferencuje př́stup jedinců k historickému vědomí.

Naznačili jsme, že v rámci analýzy jsme provedli jistá metodologická zjednodušení. V prvé řadě pracujeme s tím, že se nezabýváme přímo náboženskou pamětí, ale vírou respondenta, kdy víra je odvozována z odpovědí na otázku po praxi víry a (ne)akceptací supranaturálních sil. Výsledkem je potom rozlišení věřící vs. ateista/nevěřící. ${ }^{1}$ Místo historické paměti pak na úrovni analýzy zkoumáme historické vědomí a vztah $\mathrm{k}$ historii. V rámci textu daná zjednodušení blî̌ze vysvětlíme a odůvodníme. Cílem je zjistit, zda lidé s různým postojem k náboženství, u nichž předpokládáme odlišnou míru náboženské paměti, mají odlišné historické vědomí a zda můžeme př́ípadně na základě odlišností historického vědomí usuzovat něco více o povaze náboženské paměti.

V rámci studie dochází $\mathrm{k}$ tomu, že užíváme množství teoretických příbuzných konceptů jako např́klad historie, náboženství, historická pamět, náboženská pamět, kolektivní pamět, kulturní pamět, aj. Proto bychom na tomto místě chtěli konceptualizaci shrnout, abychom předešli možným nepochopením. Dle našeho předpokladu, opíraje se přitom o námi zpracované studie, jsou náboženství a historie propojené a jsou součástmi kolektivní paměti. Kolektivní pamět je pamětí, jež je utvářena a sdílena jedinci, kteří jsou si kulturně blízcí a zastřešuje jednak soubory myšlení,

\footnotetext{
${ }^{1}$ Jsme si vědomi, že ateisté a nevěřící nejsou totožnými pojmy, nebot za ateistu v tradičním významu považujeme člověka, který nevěří v Boha, kdežto za nevěřícího jedince takového, který nevěří v „našeho boha“. V současnosti je ale ve studiích často termín ateista zaměňován právě termínem nevěřící. My ve své studii využíváme označení ateista/nevěřící, které vychází z otázky v dotazníkovém šetření. Je to tak jedinec, který subjektivně sebe chápe bud' jako ateistu nebo nevěřícího.
} 
chování a jednání (jako je náboženství nebo historie), tak individuálně přebíraných a konstituovaných vzorců chování, jednání a myšlení (jako je náboženská či historická pamět). Vztah mezi náboženstvím a náboženskou pamětí nahlížíme jako dialektický, kdy dochází k vzájemnému ovlivnění - respektive jedinci svou sdílenou náboženskou pamětí ovlivňují náboženství jakožto soubor náboženských představ a na stranu druhou tento soubor má dále vliv na sdílenou náboženskou pamět jedinců.

Dílčí paměti jsou udržovány na jedné straně předáváním historických znalostí a na druhé straně (náboženskou) socializací. Vztahy mezi koncepty jsou propleteny a cílem následné analýzy je v určité míře zjistit, zda vztahy mezi náboženskou pamětí (vírou) a historickou pamětí (historickým vědomím) jsou propojené i na empirické úrovni či naopak bychom měli lépe odlišovat jednotlivé paměti a precizněji je definovat i na teoretické úrovni.

\section{Teoretické vymezení}

Dnes již v mezinárodním měřítku existuje nepřeberné množství teoretických děl i empirických výzkumů, které se zabývají kolektivní či kulturní pamětí stejně tak jako prací recipujících konceptualizaci paměti v teoriích a dějinách sociálněvědního myšlení (Erll, Nüning 2010; Rossington, Whitehead 2007; Radstone, Schwarz 2010). Lze konstatovat, že koncept kulturní paměti dnes vytváří určitou školu či tradici sociálně-vědního bádání, tradici, která spojuje klasiky sociálně vědního bádání s dnešními autory a jejich výzkumy. Ilustrativní je, že čítanka The Collective Memory Reader z roku 2011 obsahuje 87 textů autorů z nejrůznějších oblastí humanitních a sociálních věd od Edmunda Burkeho, Alexise de Tocquevillea, Friedricha Nietzscheho, Sigmunda Freuda a Karla Marxe přes Karla Mannheima, Waltera Benjamina a Theodora W. Adorna k Michelu Foucaultovi, Peterovi Burkemu, Yaelu Zerubavelu či Anthony Giddensovi (Olick, Vinitzky-Seroussi, Levy 2011). Navíc v sociologii koresponduje zaujetí tématem paměti s rekonstrukcí celé výzkumné oblasti, která je označována jako historická sociologie. V textech jednotlivých autorů narazíme pochopitelně na různé typologie paměti (srov. např. Lužný, Váně 2018: 13-54).

Pamět je tedy fenoménem, který v současnosti získává stále více pozornosti v sociálních vědách i v České republice. ${ }^{2}$ Náš „obrat k paměti“ v kontextu české sociologie náboženství navazuje na několik málo předcházejících studií. Podíváme-li se totiž na sociologickou literaturu od roku 1989, zjistíme, že v česko-slovenském prostoru existují tři, respektive čtyři, pokusy v podobě monografií o začlenění tématu náboženské nebo historické paměti do sociologické agendy. Dva z nich jsou přímo spojeny s tématem náboženství. Prvním počinem je práce Adély Kvasničkové Náboženstvo jako kolektívna pamät: prípad Slovenska a Čiech z roku 2005. Kvasničková se snaží poukázat na rozdíly v náboženském životě české a slovenské společnosti, přičemž rámcem pro její úvahy je skutečnost rozdělení společného státu a vznik dvou samostatných republik - České republiky a Slovenské republiky. Kvasničková se snažila využít potenciálu konceptu náboženství jako paměti, kterou přinesla v návaznosti na Maurice Halbwachse (2009) francouzská socioložka Dani?le Hervieu-Léger. Ta chápe náboženství jako formu kolektivní paměti a autorizované tradice, jejíž základem je kontinuita linie víry. Náboženství, resp. náboženská pamět tedy (s odkazem na tradici Emila Durkheima) integruje dané společenství. V moderní společnosti však dochází k oslabování celkové společenské (kolektivní) paměti, což vede k rozpadu náboženské paměti, a tedy k oslabování významu náboženství. Oslabování náboženství v moderních společnostech není dáno postupující racionalizací těchto společností, ale ztrátou paměti těchto společností, tedy

\footnotetext{
${ }^{2}$ Srov. Burzová, Dvořáková, Hejnal (2013); Huyssen (2013); Kunt, Szegö, Vajda (2013); Marková, Slach (2013); Rapošová, Sejková, Szaló (2013); Sidiropolu Janků (2013); Šubrt, Vinopal (2013); Lužný (2014); Maslowski, Šubrt (2014); Kratochvíl (2015); Tížik (2016); Vido (2016) aj.
} 
rozpadem „řetězce“ paměti (rozbitím článků řetězce), který poskytuje viřre legitimitu spojením současnosti společnosti s její minulostí (Hervieu-Léger 2000). ${ }^{3}$

V českém prostředí pak na již zmíněnou Dani?le Hevieu-Léger navazuje Barbora Spalová knihou Bůh Vi proč. Studie pamětí a režimů moci v křestanských církvích v severních Čechách (2012). Spalová provedla kvalitativní výzkum v různých křestanských komunitách v regionu s výraznou diskontinuitou způsobenou odsunem Němců. Pro naši studii je zajímavé, že Spalová ve své práci mimo jiné zkoumá, zda se odlišují praktikující věřící, věřící a nevěřící v konstruování příběhů paměti a to na př́kladu zchátrání a záchrany mařenického kostela. Dochází ke zjištění, že vyprávěné příběhy, a tudíž i pamět jedinců na toto téma se opravdu liší v závislosti na míře deklarované víry. Spalová rovněž sama poukazuje na to, že náboženská pamět je konstruována i za pomoci historie, která ji utváří jistou oporu (více viz Spalová 2012).

V návaznosti na tyto práce se snažíme prokázat provázání mezi historickým vědomím a náboženskou vírou (resp. pamětmi) a možné odlišnosti mezi praktikujícími věřícími, věřícími v síly nad námi a nevěřícími, nebot toto rozlišení se i u Spalové ukázalo jako významné pro diferenciaci v utváření paměti. Dále využíváme právě i koncepci náboženství jako paměti od Hervieu-Léger, která nám přijde přínosná ze dvou hlavních důvodů. Za prvé klade důraz na návaznost generací, tedy že náboženská pamět je předávána z generace na generaci. V rámci našich hypotéz se v elementární úrovni snažíme postihnout mezigenerační přenos skrze předávání materiálních statků. A za druhé v kontextu individualismu naráží na něco, co označuje jako tzv. konec společnosti paměti v důsledku roztříštění konceptu paměti, kdy nejsme schopni rozlišovat rodinnou pamět, náboženskou pamět, národní pamět aj. Přestává tak existovat totální kolektivní pamět, která se tříští do specializovaných pamětí v důsledku strukturální diferenciace (Hervieu-Léger 2000: 127-128). V tomto smyslu se kolektivní pamět stává problematickou a zároveň př́lišná roztříštěnost dílčích specializovaných pamětí přináší problém s definováním jednotlivých pamětí, které jen problematicky rozlišíme. Ukázkovým př́́kladem je v tomto směru např́iklad rozmanitost typologií paměti (srov. Le Goff 2007; Suleimanová 2006; Snyder 2015, aj.). Nastává problém, kdy nejsme schopni předpovědět, zda kapacita kolektivní paměti může přežít totální atomizaci paměti (Hervieu-Léger 2000: 143-149).

Oproti tomu Simone Schweber ve svém výzkumu poukazuje na to, že zmíněná atomizace je pouze relativní a to v tom smyslu, že historická a náboženská pamět jsou tím samým. Žádná historie (událost či skupina událostí) nestojí dle ní mimo náboženskou kolektivní pamět (Schweber 2006: 408). Není poté divu, že v posledních desetiletích existují různé pokusy o konceptualizaci vztahu paměti a historie (např. Assmann 2006; Barša 2011; Le Goff 2007; Nora 1984). I toto východisko nás vede ke snaze zjistit něco blíže o případném (ne)propojení náboženské paměti a historického vědomí.

Třetím pokusem o začlenění tématu historické paměti do prostředí české (či česko-slovenské) sociologie, který využíváme a jenž nám byl inspirací, je dílo Jiřího Šubrta (a dalších jeho spolupracovníků), které představuje řadu dílčích studií, jež následně vyústily do monografie Historické vědomí obyvatel České republiky perspektivou sociologického výzkumu (2013). Základním konceptem a tématem výzkumu bylo „historické vědomí“ a použitou metodologií bylo kvantitativní dotazníkové šetření. Také Šubrt (obdobně jako Kvasničková v př́ípadě pojetí náboženské paměti) narazil na problém komplikované operacionalizace obecných konceptů kolektivní paměti a historického vědomí.

Historické vědomí Šubrt chápe „nejen jako soubor znalostí, dojmů a představ o minulosti, nýbrž předevšim jako vědomi určitých souvislostí (respektive kontinuity, diskontinuity a změny)

\footnotetext{
${ }^{3}$ Dále pak Kvasničková aplikuje koncept britské socioložky Grace Davie (2000), která typologii paměti ještě rozšiřuje. Grace Davie rozlišuje mezi „vicarious memory“, „precarious memory“, „mediated memory“, „,alernative memories“ a „aesthetic or symbolic memory“ (Davie 2000).
} 
mezi minulostí (ukládanou do kolektivni paměti), př́tomností a budoucností; jako vědomí, které přispívá k vytvárení postojů lidí současnosti a budoucnosti " (Šubrt, Vinopal 2013: 15). Historické vědomí je vnitřně strukturováno a je utvářeno prostřednictvím souhry několika základních komponent. První z nich je (a) prožitá historická zkušenost, která však do jisté míry přesahuje individuální zkušenosti jednotlivých aktérů, nebot se týká spíše obsahů kolektivní (skupinové, generační, společenské či národní) povahy, a to proto, že „zážitku určitých historických událostí byly vystaveny velké skupiny lidí, a také proto, že se tyto prožité události stávají předmětem kolektivní reflexe a mezilidské komunikace“. Další komponentou je (b) ideologie, tedy "relativně ucelená soustava názorů, idejí a hodnot, založená na formulaci zájmů určité skupiny, tř́dy nebo společenství lidí. Nejdůležitější funkcí ideologie je legitimizace (legitimizace přítomnosti také prostřednictvím odkazů na minulost), což se děje tak, že ideologie „vysvětluji společenské události (včetně krizí, konfliktů a válek), stanovuji kritéria pro hodnoceni těchto událostí (ve smyslu,dobré $a$,zlé'); umožňuji svým stoupencưm identifikovat se s určitou skupinou, ziskat vědomí sounáležitosti s určitým kolektivním subjektem; a poskytuji základni východiska a principy pro formulaci určitého politického programu“. Je zřejmé, že důležitou roli v tomto ohledu hraje státní ideologie, která díky školskému systému a povinnému státnímu vzdělávání (zde Šubrt odkazuje na myšlenky Pierra Bourdieu) vštěpuje svým občanům společné formy a kategorie vnímání a myšlení a sociální rámce chápání, čímž vytváří předpoklady společenského koncensu. Třetí komponentou je (c) vědění produkované dějepisectvím a historickou vědou. Dějepisectví (historická věda) systematicky zaznamenává události a děje, které se odehrály v minulosti, resp. snaží se „za využití odborné metodologie získávat, kriticky analyzovat, systematizovat a objasňovat poznatky vztahujicí se $k$ dějinám “. Čtvrtou komponentou je d) kolektivní pamět, která je tvořena obsahy, kterými mohou být mýtické představy, pověsti, vzpomínky na historické události a osobnosti, tradice a zvyky (Šubrt, Vinopal 2013: 16-18). ${ }^{4}$

V našem pojetí povahu (náboženské) paměti určuje socializace, během níž dochází k osvojování si hodnotového rámce. Náboženská (či poté globálně kolektivní) pamět rámuje, jak jedinci vnímají sebe jako agenty historie, občany demokracie a aktéry ve světě (Schweber 2006: 408). Náboženská pamět sebou tak přináší specifické hodnoty, kterým se jedinci v rámci náboženské socializace učí. Tyto hodnoty odpovídají teologické nauce a vytváří diference mezi jedinci věřícími a neveřícími (viz Nešporová 2010; Prudký 2009; aj.). Očekávatelné je, že více se od nevěřících liší jedinci konfesně přináležející oproti jedincům, kteří Boha vnímají jako nějakou sílu nad námi (Prudký 2009: 113). Hodnoty naučené během náboženské socializace se stávají částí jedincovy paměti a spoluutvářejí jedincův pohled na svět, čímž ovlivňují to, jak jedinec světu rozumí, jak rozumí sobě samému a i to, na co cílí svou pozornost a co se mu v tomto kontextu do paměti zpětně ukládá. Z výše řečeného vyplývá, že výzkumy prokazují rozdíly či podobnosti mezi skupinami tzv. tradičně věřících, alternativně věřících a nevěřících (Hamplová 2008; Hamplová, Řeháková 2009; Hásová 2015; Vávra 2010; aj.). Námi použitá data pracují také s tímto rozdělením na praktikující (tradičně) věřící, alternativně věřící (věřící v nějaké síly nad námi) a nevěřící, kde lze předpokládat odlišnou míru náboženské paměti u jednotlivých skupin (Spalová 2012), a tudíž odlišnou souvislost $\mathrm{s}$ historickým vědomím. Z hlediska námi užitých dat jde tak o subjektivní zařazení jedince do příslušné kategorie, a nikoliv o konstruování skupin na základě složení více proměnných (Váně, Hásová 2014).

Pro nás je náboženská socializace důležitá hlavně z toho hlediska, že během ní si jedinci osvojují prostředky pro legitimaci svého postoje. Jedním z prostředků může být legitimizace postoje skrze historii a odkaz na tradici. To částečně naznačuje ve svém textu Schweber (2006: 408), když

\footnotetext{
${ }^{4}$ Čtvrtým pokusem přinést téma paměti do českého prostředí, který v této studii není tolik artikulován a slouží hlavně jako doplnění, je monografie Nicolase Maslowskiho a Jiřího Šubrta Kolektivní pamět. K teoretickým otázkám (2014), která se snaží přiblížit a v jisté míře utřídit téma kolektivní paměti na základě mnoha zahraničních teoretiků a jejich koncepcí.
} 
poukazuje na to, že náboženská pamět nestojí mimo historii. Dalšími je osvojení si specifických hodnot a schopností, jež jsou charakteristické pro praktikování víry, jako je naslouchání např. bohoslužbám či rozumění kázání či náboženské nauce. Tyto predispozice a předchozí zkušenosti mohou následně ovlivňovat porozumění a pamatování si historických faktů. A to z toho důvodu, jelikož náboženství samo o sobě zahrnuje historické příběhy, jež jsou generačně předávány a to může mít pozitivní vliv na vnímání historie jako celku. Jedinci si snáze zapamatovávají a rychleji se učí věci, které jim připadají známé (Lipson 1983: 450). Učení historických faktů poté může být pro věřící jedince snazší, jelikož ho vnímají podobně jako náboženskou nauku, kterou prošli, a zároveň si historické znalosti osvojují jako legitimizační nástroj své víry.

Náboženská socializace (primární i sekundární) je tak podle nás klíčovým faktorem pro uvažování o podobách paměti, respektive historického vědomí. A zároveň náboženská pamět se stává ústředním prostředkem, jak odolávat sekularizačním vlivům a individualizačním a pluralizačním trendům. Právě selhávání náboženské socializace je používáno jako jedno z nejčastějších vysvětlení pro pokles víry v mezigeneračním přenosu (Hamplová, Řeháková 2009; Laudátová, Vido 2010; Paleček, Vido 2014; Váně, Štípková 2013, aj.).

Konstatovali jsme, že náboženskou pamět chápeme jako součást kolektivní paměti. Stejně tak s kolektivní pamětí dáváme do souvislosti historické vědomí. Očekáváme tudíž vztah mezi mírou osvojení náboženské paměti a historického vědomí, a to i právě z hlediska potřeby věřících legitimizovat svoji víru s odkazem na historii. Jelikož nemáme dostupný nástroj, který by zjištoval kolektivní pamět v České republice, zvolili jsme historické vědomí, které se kolektivní paměti přibližuje a pro jehož měření máme již použité operacionalizace a získaná data. Historické vědomí samo se totiž vzájemně dotýká, interaguje a prolíná s mnoha oblastmi, hlavně pak se světovým názorem, morálkou, hodnotovým systémem, kolektivní mentalitou a v neposlední řadě právě s náboženstvím. Reálně se tyto fenomény prolínají a jejich hranice jsou neostré (Šubrt, Vinopal 2013: 15). Historické vědomí v tomto ohledu tedy nahlížíme jako vědomí, které přispívá k vytváření postojů lidí k současnosti a budoucnosti. Dále vycházíme z předpokladu, že toto vědomí je nějakým způsobem strukturováno, a že je tedy zapotřebí jeho struktury teoreticky identifikovat a zároveň přispět k analýze jejich fungování (Šubrt, Vinopal 2013: 15). Právě jednou z takových struktur může být náboženství, respektive náboženská paměte na jejíž fungování se zde chceme zaměřit.

Podle Jiř́ího Šubrta a Jiř́ho Vinopala můžeme rozlišit 3 základní typy historického vědomí: pozitivní afirmace, noetický instrumentalismus a historický nihilismus. Tato typologie jde dále rozšśríit na 5 typů v závislosti na aktivním zájmu o historii na: aktivní a pasivní pozitivní afirmaci, aktivní a pasivní noetický instrumentalismus a historický nihilismus. Pozitivní afirmace je spojena s názory, že historie a její poznání je důležité a musíme se starat o zachování tohoto kulturního dědictví. ${ }^{5}$ Noetický instrumentalismus odkazuje k vidění historie jako logického procesu a znalost je důležitá forma vědění, které slouží jako nástroj. ${ }^{6}$ Historický nihilismus poté znamená odmítání a zpochybňování důležitosti historie. ${ }^{7}$ Aktivita a pasivita je spojena se zájmem o historii samotnou (Šubrt, Vinopal 2013: 73-77). Na základě toho, že předpokládáme různý přístup k historickému vědomí z hlediska rozlišení mezi věřícími a nevěřícími, jsou pro nás typy historického vědomí důležité, což uvidíme následně při formulaci hypotéz.

\footnotetext{
${ }^{5}$ Charakteristické výroky pro pozitivní afirmaci: „Znalost historie je předpokladem kulturní úrovně člověka." „Lidé $v$ minulosti vytvořili hodnoty, o které se dnes můžeme opřit." „Chceme-li být hrdi na svůj národ, musíme znát svou historii." a „V historii najdeme důležité poučení pro dnešek." (Šubrt, Vinopal 2013: 73).

${ }^{6}$ Charakteristické výroky pro noetický instrumentalismus: „Historie se stále opakuje." „Všechny události na sebe navazuji, vše je důsledkem něčeho v minulosti." „Historie významně ovlivňuje náš současný život." "Kdo zná zákonitosti historie, dokáže lépe předvídat budoucnost. “ a "Znalost historie nám pomáhá řešit současné problémy." (Šubrt, Vinopal 2013: 73).

${ }^{7}$ Charakteristické výroky pro historický nihilismus: „Historický vývoj je nahodilý a těžko v něm hledat nějakou logiku." "Jedině př́tomnost je to, o co tu běži." a "Zatěžovat se historii nemá smysl." (Šubrt, Vinopal 2013: 74).
} 
Shrneme-li si výše nastíněné, vycházíme z předpokladu, že existuje podobnost mezi historickou a náboženskou pamětí a že je možné analýzou jejich možného propojení zjistit něco bliže o tom, jakou funkci má náboženská pamět ve společnosti, což by mohlo dále pomoci k navržení výzkumu zaměřující se přímo na funkci náboženské paměti. Dle našich předpokladů se možné propojení a podobnost funkce náboženské a historické paměti odvíjí od socializace a to tak, že věřící jedinci jsou častěji seznamováni s historickým kontextem, kterým legitimizují svoji víru, a získávají lepší predispozice pro zapamatování si historických faktů. Oba typy paměti bereme jako součást kolektivní paměti. Jsme si vědomi, že to přináší jisté problémy, nebot samotný koncept kolektivní paměti je v současnosti spojen s jistými riziky a omezeními (srov. Tížik 2016: 136-138). Jedním z klasických problémů při zkoumání paměti může být i jistá polysémičnost konceptu paměti a zároveň existence několika obsahově podobných konceptů (Vido 2016: 147).

\section{Hypotézy}

S odkazem na klasiky tématu Hervieu-Léger (2000), Assmann (2006) předpokládáme propojení mezi historickou pamětí a náboženstvím. V českém kontextu pak např. Šubrt a Vinopal (2013: 15) zastávají názor, že historické vědomí, tak jak jej definují, se s náboženstvím taktéž prolíná.

Věřící lidé, jak jsme nastínili v teoretické části, jsou nejen nositeli náboženské paměti, ale předpokládáme, že by měli více inklinovat k udržování kolektivní paměti a společně s tím mít i vyšší historické znalosti. Tento předpoklad dáváme do souvislosti s vlivem hostilního a sekularizovaného prostředí. V takovém prostředí potřebuje nábožensky orientovaný jedinec (komunita) opakovaně obhajovat nejen svou identitu, ale i legitimitu svého postoje. Tu čerpá z interpretací osvojených během socializace. Ústředním zdrojem legitimity se tak stává odkaz na tradice/historii. Jinak řečeno, v průběhu náboženské socializace si jedinec osvojuje specifické hodnoty a schopnosti (viz např. Nešporová 2010; Prudký 2009). Např́íklad dodržování náboženských tradic, náboženskou nauku, která v sobě zahrnuje odkazy na historické události a může jim tak v některých ohledech připadat podobně jako výuka historie. Zároveň jsou vedeni $\mathrm{k}$ tomu utvářet a udržovat vazby, jež jsou pro náboženství potřebné (i z hlediska náboženské socializace), což může taktéž přispívat k zájmu o historii a udržování kolektivní paměti.

Naopak u jedinců, kteří tyto socializované hodnoty a zkušenosti nemají, předpokládáme nižší zájem o historii a udržování kolektivní paměti. V makro rovině poté může samotná znalost historie přispět k ochraně před manipulací (Šubrt, Vinopal 2013: 48). Jedinci bez historického vědomí mohou snadněji podléhat historickým desinterpretacím, např́íklad ohledně náboženských otázek, a tím vytvářet proti-náboženskou náladu ve společnosti, která působí na věřící v tom smyslu, že přestávají vychovávat své děti ve víre, aby se nemusely s těmito negativními názory potýkat ve svém životě. A tím dochází k selhávání náboženské socializace a předávání hodnot, které by utvářely náboženskou pamět. Z těchto předpokladů vychází výzkumná otázka, zda lze na základě analýzy historického vědomí u jedinců s různou úrovní vztahu k náboženství zjistit něco bližšího o povaze náboženské paměti. Obecnou hypotézou tedy je, že věř́cí lidé maji pozitivnější vztah $k$ historii než lidé nevěrící.

Jelikož, jak jsme konstatovali výše, můžeme historické vědomí rozlišit na několik kategorií a samo historické vědomí lze chápat „nejen jako soubor znalostí, dojmů a představ o minulosti, nýbrž předevšim jako vědomí určitých souvislostí (respektive kontinuity, diskontinuity a změny) mezi minulostí (ukládanou do kolektivní paměti), př́tomností a budoucností “ (Šubrt, Vinopal 2013: 15), předpokládáme, že praktikující věřící budou vykazovat specifickou podobu historického vědomí oproti ostatním. Jelikož praktikující věřící považujeme za nositele náboženské paměti a náboženskou pamět za součást kolektivní paměti, mělo by se ukázat, že praktikující věřící se spíše kloní k pozitivní afirmaci. Jedinci, kteří se vyjádřili, že věří v nějakou supranaturální sílu, by pak 
měli logicky inklinovat k noetickému instrumentalismu a to proto, jelikož víra těchto jedinců není produktem náboženské socializace, ale je závislá na svobodné volbě, která je prvkem konzumní kultury (Prudký 2009), a tito jedinci tak spíše volí víru jako nástroj pro nějaké uspokojení potřeb, a tedy i historie by jimi měla být nahližena jako nástroj, který může být využíván. Ateisté/nevěřící by pak nejpravděpodobněji měli historii chápat spíše jako neužitečnou a inklinovat k historickému nihilismu. Tento předpoklad spojujeme s trendem dnešní doby, kdy zájem o historii obecně není př́liš velký, jak ukazují i výsledky výzkumu Šubrta a Vinopala (2013).

Zároveň předpokládáme-li u věřících jedinců vyšší tendenci udržovat kolektivní pamět, tedy v našem pojetí historické vědomí, než u lidí nevěřících, je vysoce pravděpodobné, že praktikování víry bude pozitivně ovlivňovat dosažené skóre z testu historických znalostí. Jinak řečeno, věřící lidé budou dosahovat vyššího skóre z testu historických znalostí než lidé nevěřící a i než jedinci věŕící v nějakou sílu nad námi.

Další dvě hypotézy jsou spojeny s udržováním paměti, vazeb. Praktikující věřící se budou více zajímat o rodinnou historii než ateisté/nevěřící. Už samotný sklon k udržování historického vědomí naznačuje tuto tendenci, ale zároveň také důraz na rodinné hodnoty, který je více typický pro jedince tradičně věřící. Tradičně věřící jedinci jsou totiž formováni věroukou, morálkou a praktikami vyznání, které toto implicitně i explicitně zahrnují, a ve výzkumech je poté patrné, že se od nevěřících liší v životních hodnotách, které vyznávají včetně těch rodinných. Jsou to právě tradičně věřící, kteří více podporují hodnoty spojené s tradiční rodinou (Prudký 2009: 107-112). Olga Nešporová se též zaměřovala na rozdíly v rodinném životě katolíků a nevěřících a na základě množství rodinných hodnot prokázala, že i když na jedné straně dochází ke sbližování hodnot, na straně druhé se mladí katolíci od nevěřících stále liší (Nešporová 2010).

$\mathrm{S}$ tím dále souvisí i to, že $v$ domácnostech praktikujicích věřicích se budou ve větší míře předávat materiální objekty, které by připomínaly minulost, než u ateistů/nevěř́cích. Tato hypotéza odkazuje k předpokladu, že samotná víra je více spjata s historií a tradicí z potřeby legitimizovat svůj náboženský postoj v sekularizovaném prostředí České republiky. Proto zde nezáleží na povaze materiálních objektů, tzn., že se nejedná pouze o náboženské předměty, protože nás zajímá inklinování k tradicím jako takovým a reprezentantem tradic je v tomto kontextu předávání materiálních objektů. Pokud by šlo o náboženské předměty, bylo by téměř jasné, že u ateistů/nevěřících tento druh věcí předáván nebude.

\section{Analýza a zjištění}

Základem pro analýzy byla data Sociologický výzkum historického vědomí 2010. ${ }^{8}$ Chtěli jsme tímto odhlédnout od tradičních výzkumů zaměřujících se přímo na náboženství a podívat se na problematiku z jiného úhlu pohledu (Váně, Hásová 2014). Jsme si vědomi, že jelikož výzkum více neartikuloval otázku náboženství, dochází zde ke zjednodušení, kdy nositele náboženské paměti představují jedinci, kteří odpověděli, že jsou praktikujícími věřícími. Empirický identifikátor náboženské paměti je pro nás praktikovaná víra. ${ }^{9}$ Sekundární analýza dat je v tomto ohledu limitující, přesto se domníváme, že zjištění, ke kterým dospíváme, jsou přínosná a je jim potřeba věnovat pozornost. A to z toho důvodu, že nositeli náboženské paměti, dle našich předpokladů, jsou právě

\footnotetext{
${ }^{8}$ Sběr dat pro tento výzkum provedla agentura STEM. Typem výzkumu bylo reprezentativní kvantitativní šetření provedené za pomoci osobních standardizovaných dotazníků. Dotazováni byli obyvatelé ČR starší 15 let. Sběr dat probíhal 20.10. - 5.1.2010. Výběr byl pravděpodobnostní stratifikovaný, jehož oporou byl Registr sčítacích obvodů a budov. Celkem bylo rozesláno 2320 dotazníků a návratnost byla $63 \%$ (velikost výběrového souboru 1459 respondentů). Po očištění chybějících hodnot u proměnných, které v rámci analýz používáme, pracujeme se souborem o velikosti 1276 jedinců.

${ }^{9}$ Odpověd’ na otázku: Jaký je Váš vztah k náboženství, otázkám víry? Možné odpovědi: 1) Jste praktikující věřící, 2) Věříte v nějakou sílu nad námi, ale do kostela nechodíte, 3) Jste nevěřící, ateista.
} 
hlavně praktikující věřící, jelikož jejich praxe je s vysokou pravděpodobností odrazem důsledné náboženské socializace a praxe v dětství (Váně, Štípková 2013), která je v našem textu nahlížena i jako predispozice pro získání předporozumění historickým znalostem dále v životě. Identifikování se s touto kategorií v sobě navíc zahrnuje potenciál upevňování historických znalostí skrze kontakt a komunikaci s dalšími praktikujícími věřícími, kteří se neustále v rámci hostilního prostředí odkazují na historický kontext jako legitimizační prostředek. V důsledku toho i přetrvávání víry jedinců z dětství do dospělosti může být právě schopnost svou víru legitimizovat na základě znalosti historického kontextu. V některých případech mohou být nositeli náboženské paměti i jedinci, kteří nejsou věřící v tradičním smyslu, ale přesto nějakou formu víry uznávají. Rozdíly mezi danými kategoriemi se budeme následně zabývat v analýze. Ateisté/nevěřící pak nejsou bráni jako zdroje náboženské paměti, protože jedinci, kteří se jako ateisté/nevěřící identifikují, se o náboženství ve většině případů nezajímají, jsou vůči němu indiferentní a nemohou ho přenášet ve formě paměti. ${ }^{10}$ Dalšími proměnnými vstupujícími do analýzy jsou: historické vědomí, ${ }^{11}$ zájem o historii rodu, ${ }^{12}$ předávání věcí či dokumentů v rodiněe ${ }^{13}$ skóre z testu historických znalostí, ${ }^{14}$ věk ${ }^{15}$ vzdělání ${ }^{16}$ a sociální status. ${ }^{17}$

V prvotních analýzách se zabýváme pouze vztahem mezi dvěma základními proměnnými, abychom následně mohli přistoupit $\mathrm{k}$ regresní analýze a zkoumat vztahy detailněji provázané mezi více proměnnými. ${ }^{18} \mathrm{~V}$ tabulce 1 se vztahujeme $\mathrm{k}$ naší první hypotéze, zda praktikující jedinci budou vykazovat specifickou formu historického vědomí. V tabulce 1 tak na základě řádkových \% vidíme rozdíly mezi skupinami věřících podle typu historického vědomí. Ukazuje se, že nad $50 \%$ praktikujících věřících inklinuje $\mathrm{k}$ typu označenému jako pozitivní afirmace. Od následné kategorie noetického instrumentalismu je to poté o $17 \%$ více a od historického nihilismu o $39 \%$. U věřících v sílu nad námi jsou rozdíly mezi prvními dvěma typy historického vědomí menší (o $8 \%$ ) a zcela nejmenší jsou poté u skupiny nevěřících, ateistů (o 1\%). Rozdíly v tabulce jsou statisticky významné, ale nepotvrdily se v očekávané distribuci, tzn., neprokázalo se, že zatímco pro praktikující věřící je charakteristická pozitivní afirmace, pro věřící v sílu nad námi noetický instrumentalismus a pro nevěřící historický nihilismus. Prokázaly se nám pouze takové rozdíly, že ze skupiny praktikujících věřících je opravdu nejvíce jedinců koncentrováno v první kategorii

\footnotetext{
${ }^{10}$ Samozřejmě jsme si vědomi, že mezi těmito lidmi mohou být i jedinci, kteří se aktivně proti náboženství vymezují, a tím ho v pozměněné formě v kolektivní paměti udržují, ale předpokládáme, že je to zanedbatelné množství, a proto ho v tomto př́ípadě bereme jako nepodstatné.

${ }^{11}$ Typy historického vědomí byly odvozeny z otázky: Představte si, že posloucháte rozhovor tří osob: Míly, Slávy a Vlasty. Míla říká: „Dějiny jsou podstatnou součástí kulturního dědictví, které máme po našich předcích, a proto je potřeba jejich znalost udržovat a předávat dalším generacím. "Sláva říká: „Znalost dějin je důležité pěstovat především proto, že když ji máme, můžeme ji využít k tomu, abychom dobře rozhodovali, volili správná řešení a vyhnuli se chybám.“ Vlasta ř́ká: „Znalost dějin důležitá není, protože nejdůležitější je pro nás př́itomnost a budoucnost, ne minulost." Který z těchto tří názorů je nejbližší Vašemu stanovisku?

${ }^{12}$ Součást otázky: Jakou důležitost přisuzujete znalosti různých částí historie? Možnost: rodinné historie, historie rodu. Možné odpovědi: 1) rozhodně velkou, 2) spíše velkou, 3) spíše malou, 4) rozhodně malou.

${ }^{13}$ Otázka: Máte ve Vaší rodině nějaké věci nebo dokumenty, které se předávají, aby připomínaly minulost Vaší rodiny? Možné odpovědi: 1) Ano, máme takových věcí hodně, 2) Ano, pár takových věcí máme, 3) Ne, nemáme žádné takové věci.

${ }^{14}$ Součástí dotazníku byl krátký test historických znalostí obsahující 10 otázek na historická fakta. Vznikla tak kardinální proměnná nabývající hodnot 0-10 v závislosti na správně zodpovězených otázkách.

${ }^{15}$ Otevřená otázka: Kolik je Vám let. Proměnná nabývá hodnot od 15-89.

${ }^{16}$ Otázka: Jaké je Vaše nejvyšší školní vzdělání? Možné odpovědi: 1) Základní bez vyučení, 2) Vyučen(a) bez maturity, 3) Maturita, 4) Vysoká škola.

${ }^{17}$ Otázka: Jaké je Vaše sociální postavení? Možné odpovědi: 1) student, učeň, 2) důchodce, 3) nezaměstnaný, 4) v domácnosti (nebo na MD), 5) zaměstnanec, 6) soukromý podnikatel, svobodné podnikání, 7) ostatní.

${ }^{18}$ Před samotnými analýzami jsme otestovali, zda nedochází $\mathrm{k}$ nějakému vychýlení v závislosti na věku a náboženství, kdy by se dalo například předpokládat, že ve starších věkových kategoriích je více lidí, kteří se hlásí k náboženskému vyznání, a že naopak nevěřící budou převažovat u mladší věkové kategorie. Takový trend se nám ale nepotvrdil.
} 
a další kategorie mají poměrně značný odstup, zatímco u nevěřících se největší počty jedinců rozkládají mezi první dva typy historického vědomí. ${ }^{19}$

Určitá podobnost mezi praktikujícími věřícími a jedinci, kteří věří v nějakou sílu nad námi, může indikovat blízkost něčeho, co označujeme jako indikátory tradiční a alternativní religiozity. Předcházející výzkum již naznačil, že funkce těchto různých typů religiozit se podobá ve vztahu k percepci náboženství ve společnosti (Hásová 2015). Pokud se nám tento trend bude opakovat i u dalších testovaných vztahů, budeme moci říci, že v určité míře i daná zjištění naznačují, že životní hodnoty těchto skupin mohou být podobné. Zjištění, že se nepotvrdil vztah mezi historickým nihilismem a nevěřícími, můžeme $\mathrm{z}$ dané perspektivy interpretovat tak, že ve společnosti může spíše dominovat idea instrumentalismu, tedy využívat vše zpo̊sobem, který maximalizuje zisk nebo přispěje $\mathrm{k}$ pokroku, čímž by bylo vysvětleno, proč daleko více se jedinci kloní $\mathrm{k}$ typu historického vědomí označeného jako noetický instrumentalismus než historickému nihilismu. Takováto zjištění by pak bylo možné lépe vysvětlit na mikroúrovni optikou teorie racionální volby (Lužný 2015). Stejně tak lze předpokládat, že školní docházka ovlivňuje vnímání dějin jakožto užitečných a že je možné dějiny spojovat s výroky, jimiž je charakterizován noetický instrumentalismus. Sama výuka dějepisu dle nás odráží právě nejvíce tento přístup. Vysvětlení se tak přesouvá do úrovně vzdělání namísto religiozity. Z těchto výsledků vyplývá, že první hypotéza se nepotvrdila zcela.

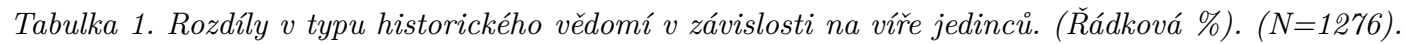

\begin{tabular}{lcccc}
\hline & $\begin{array}{c}\text { Pozitivní } \\
\text { afirmace }\end{array}$ & $\begin{array}{c}\text { Noetický } \\
\text { instrumentalismus }\end{array}$ & $\begin{array}{c}\text { Historický } \\
\text { nihilismus }\end{array}$ & Celkem \\
\hline Praktikující věřící & $52 \%$ & $35 \%$ & $13 \%$ & 166 \\
Věř́cí v síly nad námi & $47 \%$ & $39 \%$ & $14 \%$ & 454 \\
Nevěřící, ateista & $40 \%$ & $39 \%$ & $21 \%$ & 656 \\
\hline
\end{tabular}

Pozn.: Pearson's chi2, $\mathrm{P}=0,004$

V tabulce 2 testujeme hypotézu, že praktikující věřící se budou více zajímat o rodinnou historii než ateisté/nevěřící. ${ }^{20}$ Zaměřili jsme se na vztah proměnných zájem o historii rodiny a rodu v závislosti na vztahu k víre. Zde je pozorovatelný a statisticky signifikantní rozdíl mezi nevěřícími a praktikujícími jedinci. Zatímco u praktikujících věřících se o rodinnou historii zajímá velmi mnoho $43 \%$, u nevěřících pouhých $27 \%$. U věřících v síly nad námi je největší koncentrace jedinců, kteří se o rodinnou historii zajímají spíše středně. Zajímavý je i fakt, že pouze 1 \% z praktikujících věřících deklarovalo, že se o rodinnou historii vůbec nezajímá. Zatímco u věřících v síly nad námi i u nevěřících jsou tyto počty o něco málo vyšší.

V tomto vztahu se neprojevila podobnost jedinců věŕících v síly nad námi a praktikujících věřících, ale naopak se věřící v síly nad námi více podobali ateistům/nevěřícím. Vysvětlení, že $\mathrm{u}$ tohoto vztahu se projevil opačný trend než v předchozím případě, můžeme hledat v povaze

\footnotetext{
${ }^{19} \mathrm{~V}$ analýze bylo využito i rozčlenění historického vědomí do 5 kategorií, kde je dále rozlišen aktivní a pasivní přístup v závislosti na vlastním zájmu o historii. V této analýze ale nebyly mezi skupinami v aktivitě pozorovány výrazné rozdíly.

${ }^{20}$ Zde by bylo možno výzkum ještě více rozšíriit o detailnější zkoumání vztahu k rodinné historii skrze otázky nejen o důležitosti rodinné historie a historie rodu, ale také o zájem o tuto historii. Dále o to, zda v rodině hovoří o svých předcích či zda někdo z rodiny zpracoval historii rodu, genealogický strom života nebo něco podobného, v čem je shrnuta rodinná historie. A dále bychom mohli zahrnout ještě otázku po tom, do jakého období přibližně sahá znalost historie rodu, rodiny. My jsme se i v rámci určitého omezení textu věnovali otázce ohledně vnímání důležitosti rodinné historie/historie rodu, protože ji vnímáme v určité míře jako zastřešující, kdy je větší pravděpodobnost, že pokud vnímám historii rodu jako důležitou, budu se o ni více zajímat a budu se s rodinou více bavit o předcích apod.
} 
alternativních proudů. Ty většinou staví na představě individualismu, kdy si jedinec volí náboženství na základě tvorby vlastního individuálního já. Rodinné vazby u jedinců věrících v síly nad námi tak nemusí být tolik pevné jako u praktikujících věřících, u kterých navíc mưžeme očekávat vícegenerační rodiny a důraz na generační návaznost (Hervieu-Léger 2000). Tato hypotéza byla potvrzena.

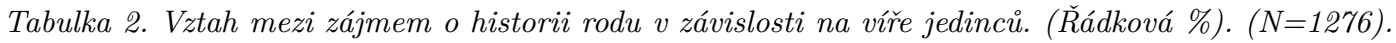

\begin{tabular}{lccccc}
\hline & & \multicolumn{3}{c}{ Zájem o rodinnou historii, historii rodu } & \\
& Velmi mnoho & Středně & Moc ne & Vůbec ne & Celkem \\
\hline Praktikující věřící & $43 \%$ & $40 \%$ & $17 \%$ & $1 \%$ & 166 \\
Věř́cí v síly nad námi & $32 \%$ & $46 \%$ & $18 \%$ & $4 \%$ & 454 \\
Nevěřící, ateista & $27 \%$ & $45 \%$ & $23 \%$ & $5 \%$ & 656 \\
\hline
\end{tabular}

Pozn.: Pearson's chi2, $\mathrm{P}=0,001$

Dále testujeme hypotézu, že v domácnostech praktikujících věřících se budou ve větší míře předávat věci, které by připomínaly minulost, než u ateistů/nevěřících. $V$ tabulce 3 tak ověřujeme vztah mezi proměnnými vztah $\mathrm{k}$ víře a předáváním věcí v rodině. I v tomto př́ípadě se opět ukázalo, že vztahy jsou sice signifikantní, ale nikoliv natolik přesvědčivé, jak jsme očekávali. Vidíme, že zase podobněji je rozloženo předávání věcí a dokumentů u praktikujících věřících a věřících v síly nad námi, kde nejvíce lidí z daných skupin odpovídalo, že mají pár takových věcí a potom následovala kategorie, že takové věci vůbec nemají. U nevěřících je tomu naopak. Nejvíce lidí se koncentrovalo v kategorii, že nemají takové věci, a pak až, že jich mají pár, rozdíl mezi kategoriemi jsou ale $2 \%$. Jinak řečeno, zatímco u nevěřících a ateistů je rozložení respondentů mezi posledními dvěma kategoriemi téměř shodné, tak u praktikujících a veřrících v síly nad námi je výraznější převaha jedinců, kteří odpověděli, že alespoň pár takových věcí mají.

U žádné skupiny není nejvyšší koncentrace jedinců v první kategorii, tedy že by jedinci v rodině předávali větší množství takovýchto věcí. Opět se projevila podobnost mezi jedinci praktikujícími a jedinci věřícími v sílu nad námi, což potvrzuje náš předpoklad o jisté podobnosti, nikoliv však stejnosti mezi indikátory tradiční a alternativní religiozity, jak se nám ukázalo u předchozího vztahu. Zde by také mohla přijít námitka předchozího vysvětlení, že jedinci věřící v síly nad námi nemají pevné vazby v rodině, a tudíž zde panuje menší zájem o rodinnou historii. Na základě dalšího zjištění můžeme zpřesnit vysvětlení, že se může jednat o rozdíl mezi vztahy v nukleární a rozšířené rodině. Jinými slovy, zatímco u praktikujících věřících se může jednat o důraz na rozšířenou rodinu, u jedinců věřících $v$ síly nad námi se jedná spíše o důležitost nukleární rodiny, kde rodinná historie nemá takový význam, ale předávání věcí či dokumentů probíhat může. Poslední hypotézu můžeme označit jako ne zcela jasně průkaznou.

Tabulka 3. Vztah mezi potřebou předávat si v rámci rodiny nějaké věci nebo dokumenty a vírou jedincư.

(Řádková \%). (N=1276).

\begin{tabular}{lcccc}
\hline & \multicolumn{2}{c}{ Vlastnictví věcí nebo dokumentů, které se v rodině předávají } \\
& Ano, máme & Ano, pár & Ne, nemáme & Celkem \\
\hline Praktikující věřící & $11 \%$ & $54 \%$ & $36 \%$ & 166 \\
Věřící v síly nad námi & $7 \%$ & $54 \%$ & $39 \%$ & 454 \\
Nevěřící, ateista & $6 \%$ & $46 \%$ & $48 \%$ & 656 \\
\hline
\end{tabular}

Pozn.: Pearson's chi2, $\mathrm{P}=0,003$ 
Pro ověření hypotézy, praktikování víry bude pozitivně ovlivňovat dosažené skóre z testu historických znalostí, jsme využili lineární regresní analýzu a postupné odhadování jednotlivých, hierarchicky konstruovaných modelů (viz tabulka 4). Pro porovnání výhodnosti modelů využíváme statistiku BIC, která je schopna ohodnotit nejlepší model i se zohledněním počtu zapojených proměnných.

Nejdříve jsme odhadli tzv. baseline model, který zjištuje vliv zvolených sociodemografických charakteristik - věk, vzdělání a sociální status. Tyto proměnné se ukázaly jako důležité při zjištování ovlivnění možnosti dosáhnout vyššího skóre z testu historických znalostí (Šubrt, Vinopal 2013), a proto jsme považovali za nezbytné je do modelu zahrnout. Baseline do analýzy zahrnujeme hlavně proto, abychom zjistili, jak probíhá vzájemné ovlivnění s nezávislými proměnnými, kterými jsou vztah k viře a typ historického vědomí. Primárně nás zajímá proměnná vztah k víre, ale považovali jsme za důležité zahrnout a kontrolovat i vliv typu historického vědomí. V tabulce 4 vidíme, že všechny zvolené sociodemografické charakteristiky jsou ve všech modelech statisticky signifikantní nebo alespoň marginálně statisticky signifikantní. Zatímco Model 1 ukazuje při zapojení proměnné vztah k víře do modelu, že i tato proměnná je statisticky signifikantní, a to ve smyslu, že praktikujícím věřícím se přidává přibližně 0,5 bodu a věrícím $\mathrm{v}$ síly nad námi přibližně 0,4 bodu z 10 bodového rozmezí skóre testu historických znalostí, v dalších modelech se tato signifikance ztrácí a snižují se i koeficienty. Po kontrole dílčích testů jsme ověřili, že je to způsobené tím, že proměnná vztah k víře je sama ovlivněna jak vzděláním, tak ještě více sociálním postavením. Proto se v prvním modelu vztah ukazuje jako platný, ale následně mizí, protože zapojujeme proměnné, které jsou za daným vztahem, jež proměnná vztah k víře v prvním modelu zprostředkovávala.

Dále testujeme vliv proměnné typ historického vědomí, kterou zahrnujeme samostatně do Modelu 2, se sociodemografickými charakteristikami poté do Modelu 4 a následně společně i se vztahem k viřre do Modelu 5. Ukazuje se, že typ historického vědomí ovlivňuje skóre z testu historických znalostí mnohem více než vztah k víře a zároveň do určité míry potlačuje, stejně jako sociodemografické charakteristiky, vliv právě vztahu k víře. Byly proto testovány i modely interakční, avšak neprokázalo se žádné zlepšení modelu. Žádná z kategorií jak historického vědomí, vzdělání, tak sociálního postavení nebyla výrazně statisticky signifikantní. Proto zde interakční modely nejsou uvedeny. Z porovnání modelů v Tabulce 4 vidíme, že nějaký vztah mezi proměnnými existuje. Poslední model vysvětluje sice nejvíce variability $(22,86 \%)$, ale statistika BIC poukazuje na to, že nejvýhodnějším modelem je Model 4, tedy ten, ve kterém nezahrnujeme proměnnou vztahu $\mathrm{k}$ víre. Už z předcházejících modelů to není zas tak překvapivé, protože se mimo jednoho modelu neukázalo, že by proměnná vztahu k víře měla významný efekt na skóre z testu historických znalostí, ale spíše jen zprostředkující. Zcela logicky se pak ukazuje, že počet získaných bodů ovlivňuje hlavně vzdělání a sociální postavení, kdy můžeme konstatovat, že nejlépe by na tom měli být vysokoškolští studenti.

Lineární regresní analýza ukázala, že vztah z hypotézy o vztahu mezi proměnnou vztah k víre a skórem z testu historických znalostí není kauzálně platný a nemůžeme jej očekávat v cílové populaci. Na základě analýzy je možné říci, že věřící jedinci mají opravdu vyšší historické znalosti, ale není to způsobené vírou jako spíše kulturním kapitálem a socioekonomickým statusem, což ovlivňuje i samotnou proměnnou vztahu $\mathrm{k}$ víre. Proto se vliv vztahu $\mathrm{k}$ víře prokázal pouze v prvním modelu, kde nebyly zapojeny kontrolní proměnné. Ani tak vliv nebyl výrazně silný, u praktikujících věřících se jednalo o efekt nárůstu 0,54 bodu z 10 oproti nevěřícím a u jedinců věřících $\mathrm{v}$ síly nad námi byl efekt ještě menší a to 0,35 bodu. Tento efekt poté zcela vymizel po zapojení dalších proměnných, z čehož jsme mohli usoudit, že ovlivnění přes vztah k víře je nepřímé. Navíc po porovnání modelů se ukázalo, že zapojení proměnné vztahu k víře do modelu není vhodné. Tímto zjištěním došlo k zamítnutí druhé hypotézy v námi představené podobě. 
Tabulka 4. Modely OLS regrese ověřujici ovlivnění skóre z testu historických znalostí vírou, typem historického vědomí a vybranými socio-demografickými charakteristikami. (Standardizované koeficienty) (N=1276).

\begin{tabular}{|c|c|c|c|c|c|c|}
\hline $\begin{array}{l}\text { Skóre z testu historických znalostí } \\
(0-10)\end{array}$ & baseline & M1 & M2 & M3 & M4 & M5 \\
\hline \multicolumn{7}{|c|}{ Vztah $k$ víre (kontrast: nevěřici, ateisté) } \\
\hline \multirow[t]{2}{*}{ praktikující věřící } & & $0,54^{* *}$ & & $0,36 \dagger$ & & 0,26 \\
\hline & & $(0,21)$ & & $(0,20)$ & & $(0,19)$ \\
\hline \multirow[t]{2}{*}{ věřící v sílu nad námi } & & $0,35^{*}$ & & 0,22 & & 0,15 \\
\hline & & $(0,15)$ & & $(0,13)$ & & $(0,13)$ \\
\hline \multicolumn{7}{|c|}{ Typ historického vědomí (kontrast: pozitivní afirmace) } \\
\hline \multirow[t]{2}{*}{ noetický instrumentalismus } & & & $-0,53^{* * *}$ & & $-0,35^{* *}$ & $-0,34^{*}$ \\
\hline & & & $(0,14)$ & & $(0,13)$ & $(0,13)$ \\
\hline \multirow[t]{2}{*}{ historický nihilismus } & & & $-2,09 * * *$ & & $-1,37 * * *$ & $-1,34^{* * *}$ \\
\hline & & & $(0,18)$ & & $(0,18)$ & $(0,18)$ \\
\hline \multicolumn{7}{|l|}{ Vzdělání (kontrast základní) } \\
\hline \multirow[t]{2}{*}{ vyučen } & $0,72^{* *}$ & & & $0,77^{* * *}$ & $0,59^{* *}$ & $0,63^{* *}$ \\
\hline & $(0,23)$ & & & $(0,23)$ & $(0,22)$ & $(0,23)$ \\
\hline \multirow[t]{2}{*}{ středoškolské (s maturitou) } & $1,94^{* * *}$ & & & $1,91^{* * *}$ & $1,60 * * *$ & $1,63^{* * *}$ \\
\hline & $(0,23)$ & & & $(0,23)$ & $(0,23)$ & $(0,23)$ \\
\hline \multirow[t]{2}{*}{ vysokoškolské } & $3,13^{* * *}$ & & & $3,14^{* * *}$ & $2,70 * * *$ & $2,71^{* * *}$ \\
\hline & $(0,27)$ & & & $(0,27)$ & $(0,27)$ & $(0,27)$ \\
\hline \multirow[t]{2}{*}{ Věk (15-89) } & $0,02^{* *}$ & & & $0,02^{* *}$ & $0,02^{* *}$ & $0,02^{* *}$ \\
\hline & $(0,01)$ & & & $(0,01)$ & $(0,01)$ & $(0,01)$ \\
\hline \multicolumn{7}{|l|}{ Sociální status (kontrast: student) } \\
\hline \multirow[t]{2}{*}{ důchodce } & $-1,12^{* *}$ & & & $-1,17^{* *}$ & $-0,97^{*}$ & $-1,01^{*}$ \\
\hline & $(0,41)$ & & & $(0,41)$ & $(0,40)$ & $(0,40)$ \\
\hline \multirow[t]{2}{*}{ nezaměstnaný } & $-2,41 * * *$ & & & $-2,43^{* * *}$ & $-2,21^{* * *}$ & $-2,23^{* * *}$ \\
\hline & $(0,38)$ & & & $(0,38)$ & $(0,37)$ & $(0,37)$ \\
\hline \multirow[t]{2}{*}{ v domácnosti } & $-1,55^{* * *}$ & & & $-1,62^{* * *}$ & $-1,28 * * *$ & $-1,33^{* * *}$ \\
\hline & $(0,39)$ & & & $(0,39)$ & $(0,38)$ & $(0,38)$ \\
\hline \multirow[t]{2}{*}{ zaměstnanec } & $-1,24^{* * *}$ & & & $-1,27 * * *$ & $-1,04^{* * *}$ & $-1,06^{* * *}$ \\
\hline & $(0,31)$ & & & $(0,31)$ & $(0,30)$ & $(0,30)$ \\
\hline \multirow[t]{2}{*}{ podnikatel } & $-1,09^{* *}$ & & & $-1,10^{* *}$ & $-0,90^{* *}$ & $-0,91^{*}$ \\
\hline & $(0,37)$ & & & $(0,37)$ & $(0,36)$ & $(0,36)$ \\
\hline \multirow[t]{2}{*}{ ostatní } & $-2,66^{* *}$ & & & $-2,66^{* *}$ & $-2,12^{* *}$ & $-2,13^{*}$ \\
\hline & $(0,87)$ & & & $(0,87)$ & $(0,85)$ & $(0,85)$ \\
\hline \multirow[t]{2}{*}{ Konstanta } & $5,23^{* * *}$ & $6,25^{* * *}$ & $7,02^{* * *}$ & $5,16^{* * *}$ & $5,81^{* * *}$ & $5,75^{* * *}$ \\
\hline & $(0,26)$ & $(0,09)$ & $(0,10)$ & $(0,27)$ & $(0,27)$ & $(0,28)$ \\
\hline $\mathrm{R} 2$ & $19,05 \%$ & $0,74 \%$ & $9,44 \%$ & $19,35 \%$ & $22,71 \%$ & $22,86 \%$ \\
\hline $\mathrm{F}$ & 29,78 & 4,77 & 66,32 & 25,26 & 30,93 & 26,69 \\
\hline (df1:df2) & $(10 ; 1265)$ & $(2 ; 1273)$ & $(2 ; 1273)$ & $(12 ; 1263)$ & $(12 ; 1263)$ & $(14 ; 1261)$ \\
\hline $\mathrm{BIC}$ & 5671,08 & 5874,07 & 5757,13 & 5680,64 & 5626,41 & 5638,31 \\
\hline (df) & 11 & 3 & 3 & 13 & 13 & 15 \\
\hline
\end{tabular}

Zdroj: Sociologický výzkum historického vědomí; vlastní výpočty Pozn.: $\dagger<0,1 ;{ }^{*} p<0,05 ;{ }^{* *} p<0,01 ;{ }^{* * *} p<0,001$ 
Výsledek, že mezi danými skupinami nejsou tak výrazné rozdíly v testování historických znalostí, považujeme za překvapivý. Je otázkou, do jaké míry může neprokázání tohoto vlivu být důsledkem sekularizace a přibližování nějakých hodnot věřících a nevěřících, a do jaké míry je to nastavením otázek v konkrétním testu. Rozhodně se ale ukazuje, že vztah mezi náboženskou a historickou pamětí není neproblematicky provázaný, ale jsou zde určité odchylky.

V celkovém pohledu se tak na základě analýzy ukazuje propojení historického vědomí a náboženské paměti jako ne tak zcela př́mé, jak jsme očekávali a jak by se i dle teoretických textů mohlo zdát. Došlo k tomu, že vztahy v hypotézách se bud’ nepotvrdily anebo ne v takové míre, jak jsme předpokládali. Můžeme se tedy domnívat, že zatímco v některých případech náboženskou pamět můžeme ztotožnit $\mathrm{s}$ historickou nebo ji brát jako její součást, v jiných se ukazuje, že tento vztah funkční není. Pokud se na výsledky podíváme komplexněji, spíše se zdá, že na individuální úrovni, pro kterou jsme měli testovatelná data, se jedná o vztah rodinného prostředí a paměti. Respektive, jedinec se narodí do rodiny, která má určitý kulturní kapitál, a ten má možnost ovlivnit, zda jedinec bude nebo nebude praktikujícím věřícím. A zároveň má kulturní kapitál rodiny vliv i na přístup k historii, který daný jedinec poté má. Podporou pro toto stanovisko bylo obrácení vztahu praktikované víry a předávání věcí v rodině, kdy jsme předávání věcí v rodině vzali jako součást kulturního kapitálu rodiny a byl zde potvrzen vztah. Zde si ale zároveň musíme uvědomit, že naše analýza byla v určité míře omezena a dané výsledky tak mohou být závislé i právě na daném omezení. A proto může tento článek sloužit i jako podnět pro bližší prozkoumání daného tématu.

\section{Závěr}

V předkládané studii jsme se snažili o bližší prozkoumání vztahu mezi náboženskou a historickou pamětí. Záměrem textu bylo testovat předpoklad propojení postoje k víře a historického vědomí, respektive zda můžeme na základě výzkumu historického vědomí obyvatel ČR říci něco o tom, jak víra diferencuje jedincův prrístup $\mathrm{k}$ historii. Náboženská pamět byla pro potřeby analýzy zúžena na víru praktikujících věřících, věřících $\mathrm{v}$ síly nad námi a nevěřících, kdy jsme předpokládali odlišnou míru náboženské paměti, kterou jedinci vlastní. Očekávali jsme, že pamět praktikujících věřících bude nejvíce podobná historické paměti a u dalších skupin se síla propojení bude zmenšovat. Už samotný vztah mezi typem historického vědomí a praktikovanou vírou se ukázal jako ne zcela jasný, a nebylo proto možné komparovat, zda se vliv historického vědomí na další proměnné podobá funkci náboženské paměti. Ta byla zkoumána dáváním do souvislosti s dalšími proměnnými zabývajícími se historií, abychom zjistili, zda můžeme mluvit o propojení náboženské a historické paměti na základě stanovených hypotéz, a tedy o tom, že víra diferencuje jedincův pohled na historii.

Hlavními zjištěními z analýz je, že propojení náboženské paměti s historickou není tak průkazné, jak jsme očekávali. Přesto můžeme shrnout alespoň elementární zjištění, která se váží k náboženské paměti, a to ve smyslu vztahu (ne)praktikované víry nejen k historickému vědomí. Z analýz vyplynulo, že můžeme identifikovat jisté rozdíly mezi vymezenými skupinami. Ukázalo se, že praktikující věřící o něco více inklinují k typu historického vědomí pozitivní afirmace, zatímco nevěřící se koncentrují mezi typy pozitivní afirmace a noetického instrumentalismu namísto historického nihilismu. Nepodařilo se propojit ani vztah mezi dosaženým skórem z testu historických znalostí, kde se výrazně projevil rozdíl mezi funkcí historického vědomí a vztahu k víre. Zatímco přidání proměnné typu historického vědomí statisticky signifikantně ovlivňovalo skóre z testu historických znalostí a zároveň přidání této proměnné do analýzy bylo statistickým testem BIC označeno jako pozitivní, proměnná vztahu k viřre se v tomto kontextu ukázala jako nadbytečná nemající výrazný přínos pro vysvětlení poklesu nebo nárůstu počtu bodů z testu. Přesto 
můžeme konstatovat, že testování vztahu proměnné vztahu k víře a dosaženého skóre z testu bylo př́nosné, jelikož na základě daných zjištění jsme reformulovali vztahy mezi testovanými proměnnými. Nyní předpokládáme, že na individuální úrovni záleží na rodinném prostředí, do kterého se člověk narodí, tedy na určitém kulturním kapitálu rodiny, který ovlivňuje jak možnost jedince stát se věřícím či nikoliv, tak jeho predispozice $\mathrm{k}$ pozitivnímu vztahu $\mathrm{k}$ historii a zároveň vzájemné ovlivňování víry a vztahu $\mathrm{k}$ historii. $\mathrm{V}$ realitě to může znamenat to, že jedinec, který je vychováván v nábožensky založené rodině, může přijmout nebo nepřijmout víru, ale na základě dané výchovy může už získat predispozice k pozitivnímu vztahu k historii, i když se nestane praktikujícím věřícím. Naznačuje to tedy námi předpokládanou funkci historie jako legitimizačního nástroje.

Dalším zjištěním pak byla podobnost mezi praktikujícími věřícími a věřícími v síly nad námi v některých zkoumaných aspektech, což v určité míře opět poukázalo na podobnost životních hodnot mezi danými skupinami, jak tomu bylo i u předešlého výzkumu (Hásová 2015). Ukazuje se tak, že indikátory, které bývají označovány jako tradiční a alternativní religiozita, mají v některých př́padech podobnou funkci.

Samozřejmě námi prezentovaná zjištění, jak již bylo uvedeno výše, podléhají také kritickému zhodnocení dostupného datového souboru, kdy muselo dojít k určitým zjednodušením kvůli sekundární analýze dat. Tato zjednodušení jsme se v textu snažili obhájit a jsme přesvědčeni, že jsme námi představenou analýzou dospěli k zajímavým výsledkům a reformulacím vztahů, které mohou být podnětem pro bližší zkoumání této problematiky a tedy navržení vlastního výzkumu, který bude zaměřen přímo na postihnutí vztahu mezi kulturním kapitálem, historickou a náboženskou pamětí. Takovéto rozšśření by pak mohlo spolehlivěji vypovídat o možnosti propojení těchto fenoménů a také o jejich možné podobné funkci ve společnosti.

\section{Financování}

Tato studie byla podpořena projektem GAČR, č. 14-01948S, Kontinuita a diskontinuity v náboženské paměti v České republice.

\section{Bibliografie}

Assmann, J. 2006. Religion and cultural memory. Stanford: Stanford University Press.

Barša, P. 2011. Pamět a genocida. Úvahy o politice holocaustu. Praha: Argo.

Bruce, S. 1992. Religion and Modernization: Sociologists and Historians Debate the Secularization Thesis. New York: Oxford University Press.

Burzová, P., I. Dvořáková, O. Hejnal. 2013. „Pamět a prostor: Reprezentační strategie společenstva vzpomínání v postindustriálním městě." Sociálni studia 10 (4): 107-126.

Cigán, J. 2013. „Náboženská konverzia ako kolektívne rozpomínanie.“ Sociální studia 10 (2): 63-83.

Davie, G. 2000. Religion in Modern Europe: A Memory Mutates. Oxford: University Press.

Erll, A., A. Nüning (eds.). 2010. A Companion to Cultural Memory Studies. Berlin: De Gruyter.

Halbwachs, M. 2009. Kolektivní pamět. Praha: SLON.

Hamplová, D. 2008. „Čemu Češi veří: dimenze soudobé české religiozity. "Sociologický časopis 44 (4): 703-723.

Hamplová, D., B. Řeháková. 2009. Česká religiozita na počátku 3. tisíciletí. Praha: Sociologický ústav AV ČR.

Hásová, V. 2015. „Where is it heading? Religion in late modernity in the Czech Republic.“ Pracovni texty Katedry sociologie FF ZČU 01/2015 [dostupné na: http://ff.zcu.cz/kss/veda-vyzkum/pracovni-texty/ 2015/Hasov_01-15_Where-is-it-heading.pdf].

Hervieu-Léger, D. 2000. Religion as a Chain of Memory. New Brunswick: Rutgers University Press.

Huyssen, A. 2013. „Berlínské proluky.“ Sociální studia 10 (4): 15-34.

Kratochvíl, A. (ed.). Pamět a trauma pohledem humanitních věd. Praha: Akropolis. 
Kunt, G., D. Szegö, J. Vajda. 2013. „Politická komunikace v příbězích zneuctěných památníků. “ Sociální studia 10 (4): 35-56.

Kvasničková, A. 2005. Náboženstvo jako kolektívna pamät: prípad Slovenska a Čiech. Bratislava: Univerzita Komenského v Bratislavě.

Laudátová, M., R. Vido. 2010. „Současná česká religiozita v generační perspektivě.“ Sociální studia 7 (4): $37-61$.

Le Goff, J. 2007. Pamět’ a dějiny. Praha: Argo.

Lipson, Y. M. 1983. „The Influence of Religious Affiliation on Children's Memory for Text Information." Reading Research Quarterly 18 (4): 448-457, http://dx.doi.org/10.2307/747379.

Lužný, D. 2014. „Kulturní pamět jako koncept sociálních věd.“ Studia Philosophica 61: 3-18.

Lužný, D. 2015. „Teorie racionální volby v současné sociologii náboženství. “ Sociológia 47 (2): $151-170$.

Lužný, D., J. Váně. 2017. „Koncept kolektivní paměti - základní východiska a závěry. “ Historický časopis 65 (4): 577-590.

Lužný, D., J. Váně. 2018. „Theory. “ Pp. 13-54 in J. Váně a kol. Continuity and Discontinuities of Religious Memory in the Czech Republic. Brno: Barrister \& Principal.

Marková, B., O. Slach. 2013. „Governance kulturou tažené urbánní regenerace: Případová studie Černá louka v Ostravě." Sociální studia 10 (4): 127-143.

Maslowski, N., J. Šubrt. 2014. Kolektivní pamět. K teoretickým otázkám. Praha: Karolinum.

Nešporová, O. 2010. „Jak náboženství ovlivňuje rodinný život?" Lidé města 12 (1): 61-88.

Nora, P. 1984. „Entre Mémorie et Histoire. La problématique des lieux." Pp. XV-XLII in Les lieux de mémoire (1. díl). Paris: Gallimard.

Olick, J. K., V. Vinitzky-Seroussi, D. Levy (eds.). 2011. The Collective Memory Reader. Oxford: Oxford University Press.

Paleček, A. 2015. „Sekularizace v pohledu inter- a intragenerační transmise: ČR ve srovnání postkomunistických zemí střední Evropy." Naše společnost 13 (2): 13-26, http://dx.doi.org/10.13060/ 1214438X.2015.2.13.231.

Paleček, A., R. Vido. 2014. „Náboženské vyznání v České republice z perspektivy inter- a intragenerační transmise." Naše společnost 12 (2): 24-35, https://doi.org/10.13060/1214438X.2014.2.12.124.

Prudký, L. (ed.). 2009. Studie o hodnotách. Plzeň: Aleš Čeněk.

Radstone, S., B. Schwarz (eds.). 2010. Memory. Histories, Theories, Debates. New York: Fordham University Press.

Rapošová, I., A. Sejková, C. Szaló. 2013. „Zabúda Brno na Zbrojovku? Praktiky formovania urbánnej pamäti prostredníctvom individuálnej angažovanosti aktérov." Sociální studia 10 (4): 79-105.

Rossington, M., A. Whitehead (eds.). 2007. Theories of Memory. A Reader. Baltimore: The Johns Hopkins University Press.

Schweber, S. 2006. „Fundamentally 9/11: The Fashioning of Collective Memory in a Christian School.“ American Journal of Education 112 (3): 392-417, https://doi.org/10.1086/500714.

Sidiropolu Janki̊, K. 2013. „Krajina vzpomínek. Kdo kreslí mapu brněnského Bronxu?“ Sociální studia $10(4): 57-78$.

Snyder, T. 2015. „Pamět suverenity a suverenita nad pamětí. Polsko, Litva a Ukrajina 1939-1999. “ Pp. 83-107 in T. Snyder, P. Kůrka. Politika života a smrti. Břeclav: Malovaný kraj.

Spalová, B. 2012. Bůh ví proč. Studie pamětí a režimů moci v křest’anských církvích v severních Čechách. Brno: CDK.

Suleiman, S. R. 2006. Crises of Memory and the Second World War. Cambridge: Harvard University Press.

Šubrt, J., J. Vinopal (eds.). 2013. Historické vědomí obyvatel České republiky perspektivou sociologického výzkumu. Praha: Karolinum.

Tížik, M. 2016. „Náboženská reprodukcia medzi kolektívnou pamätou a silou zákonov." Pp. 117-142 in E. Laiferová, L. Mistríková. Dvadsatpät rokov sociologickej rozmanitosti. Bratislava: Univerzita Komenského v Bratislavě.

Univerzita Karlova. Filozofická fakulta. Katedra sociologie. Sociologický výzkum historického vědomí [datový soubor] [online]. Ver. 1.0. Praha: Český sociálněvědní datový archiv, 2013 [citováno 13. 10. 2015], https://doi.org.10.14473/CSDA00132.

Váně, J., M. Štípková. 2013. „The National Religious Environment and the Orthodoxy of Christian Beliefs: A Comparison of Austria, the Czech Republic and Slovakia." Sociologický časopis 49 (3): 403-425. 
Váně, J., V. Hásová. 2014. „Jak se v České republice vlastně měří náboženství?“ Acta Fakulty filozofické Západočeské univerzity v Plzni 6 (3): 139-169.

Váně, J., V. Hásová. 2017. „Jaká je spolehlivost odhadu přenosu náboženství mezi rodiči a dětmi?“ Naše společnost 15 (1): 3-13, https://doi.org/10.13060/1214438X.2017.1.15.364.

Vávra, M. 2010. „Náboženství a kvalita života. Psycho-sociální předpoklady. "Naše společnost 8 (2): 3-10.

Vido, R. 2016. „Možnosti konceptu paměti pro sociologické studium náboženství v české společnosti."

Pp. 143-173 in E. Laiferová, L. Mistríková. Dvadsatpät rokov sociologickej rozmanitosti. Bratislava: Univerzita Komenského v Bratislavě.

\section{O autorech}

Veronika Hásová se zaměřuje na témata z oblasti sociologie náboženství a sociologie komunit. Ke zkoumání těchto témat využívá kvalitativní i kvantitativní metody, převážně pak etnografii a regresní modely. V současném výzkumu zkoumá funkci komunity na pozadí moderních trendů se zaměřením na individualizaci a snaží se tak o redefinici daného konceptu.

Jan Váně je vedoucím Katedry sociologie, Západočeské univerzity v Plzni. Ve svých výzkumech se soustředí na srovnávací výzkum z oblasti sociologie náboženství (individualizace, mezigenerační přenos religiozity, náboženská kulturní pamět, morfování náboženských komunit); sociologii vzdělání (tvorba a volba vzdělávacích strategií jak na straně aktéra tak systému) a problematice bezdomovectví a sociálních služeb poskytovaných skupinám sociálně nejslabších. Dále se pak věnuje sociálním teoriím akcentující problematiku spravedlnosti a metodologickým inovacím ve výzkumu. ORCID: https://orcid.org/0000-0002-5109$505 \mathrm{X}$.

Jiří Vinopal je vedoucím Katedry sociologie na Filozofické fakultě Univerzity Karlovy. Zaměřuje se na metodologii sociologického výzkumu, a to především na problematiku dotazníkových šetření, standardizovaného dotazování a jeho kognitivních aspektů. Mezi další oblasti odborného zájmu patří teoretické a metodologické aspekty zkoumání veřejného mínění, metodologie výzkumu kvality pracovního života a sociologická analýza role piva a pohostinských zařízení v České společnosti.

Dušan Lužný je vedoucím Katedry sociologie a andragogiky, Univerzity Palackého v Olomouci. Jeho výzkumy se zaměřují na sociologii náboženství, nových náboženských hnutí a sociologickou teorii.

\section{Summary}

In our text, we focus on the function of memory in connection with religious faith. We base our work on the assumption that, as a result of modern trends with an emphasis on individualism, memory is something that is endangered. On the other hand, memory is still a significant element, as it is a crucial source of identity and it is thus important to focus on its operation. Specifically, we are interested in using available data to gain knowledge on the differentiation of the relationship towards history (i.e. a certain historical memory) via attitudes towards religious faith. We link these two elements, as various theoretical concepts have shown that history and faith are linked to one another (Kvasničková 2006; Schweber 2006; Spalová 2012; Šubrt, Vinopal 2013; etc.). We then assume that history serves as a legitimizing tool of faith. In other words, believers are much more often confronted with the justification of their religious attitude and in our opinion this justification takes place with a reference to history, i.e. to specific historical events with a legitimizing potential.

Based on these concepts, we have established a general hypothesis that believers have a more positive relationship towards history than non-believers. We divide the general hypothesis into four specific hypotheses, which relate to the data that we have available. Firstly, we assume that practicing believers will show a specific form of historical knowledge different to others, i.e. practicing believers will have a tendency towards a type of historical knowledge called "positive affirmation". Individuals who express their belief in a supernatural force will have an inclination towards noetic instrumentalism. Atheists/non-believers will be more likely to understand history as being less useful and have a tendency towards historical nihilism. Secondly, we assume that practicing faith will positively influence the score received from a test of historical knowledge. In other words, believers will receive higher scores on tests of historical knowledge than non-believers and those believing in a stronger supernatural force. Thirdly, we assume that practicing 
believers will be more interested in family history than atheists/non-believers. Fourthly, objects that are reminiscent of the past will be passed down to a greater degree in the households of practicing believers than in those of atheists/non-believers.

We have attempted to verify the hypotheses based on the analyses we have carried out, which have shown that not all assumptions are clearly provable based on available data. For example, the relationship between the attitude towards religious faith and scores on the test of historical knowledge was not proven. It was found that this relationship is more mediated through cultural capital and socioeconomic status. On an individual level, it depends on the family environment that a person is born into, i.e. the certain cultural capital of the family, which influences the opportunity of an individual to become a believer or not and thus their predisposition towards a positive relationship towards history and at the same time the mutual influencing between faith and the relationship towards history. In reality, this may mean that the individual that is raised in a religious family can accept or not accept faith, but may gain predispositions to a positive relationship towards history based on their upbringing even if they do not become practicing believers.

On the other hand, we can claim that practicing believers have a truly different approach to historical knowledge than that of the other two categories (believers in supernatural forces, atheists/non-believers) and the fact that they have the greatest tendency towards the type of historical knowledge known as positive affirmation, which is linked to statements such as "Knowledge of history is a prerequisite for a person's cultural level", "People in the past have created values that we can rely on today", and "We can find important lessons in history for today's world" (Šubrt, Vinopal 2013: 73). Based on the data used, we can claim that practicing individuals truly have a more positive relationship towards history than non-believers. Our findings thus point out the suitability of researching the given topic and its possible expansion based on data aiming at representing the relationship between faith and history. 